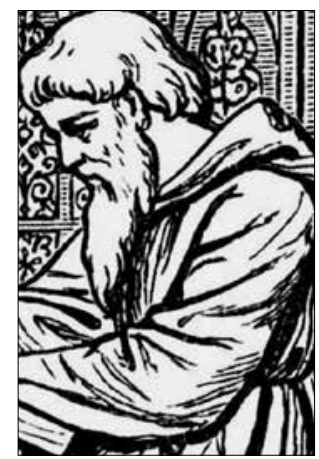

\title{
JONO SOLSBERIEČIO POLIKRATIKAS ARBA APIE DVARIŠKIŲ PRAMOGAS IR FILOSOFŲ UŽSIĖMIMUS
}

\author{
John of Salisbury's Policraticus or On the Frivolities \\ of Courtiers and the Footprints of Philosophers
}

\section{PROLOGAS}

Visų malonių dalykų maloniausias yra rašto vaisius, nes apsaugo nuo slegiančių vietos ir laiko ribu, suburia draugus, palaiko jų santykius ir neleidžia, kad patirties verti dalykai liktu nepastebėti. Juk ir menai pražūtu, i̇statymai išnyktu, tikèjimo ir visos aliai vienos religijos tarnystės žlugtu, ir pats teisingas iškalbos naudojimas būtu apleistas, jeigu dieviškoji užuojauta kaip vaistą nuo žmogiškojo silpnumo mirtingiesiems naudojimąsi raidèmis nebūtų parūpinusi. Protèvių darbų pavyzdžiai, kurie yra dorumo paskata ir palaikymas, visiškai nieko nę̨kvėptų ir neskatintų, jeigu uolus rašytojų rūpestis ir tinginystę nugalintis jų stropumas būsimoms kartoms tụ pavyzdžiu neperduotų.

Jei iš tiesu gyvenimo trumpumas, supratimo lètumas, neveiklumo abejingumas ir užsiėmimo bergždumas leidžia mums nedaug sužinoti, tai net ir tai tuojau pat iš sielos atima ir nusineša žinojimo apgavikas, atminties patèvis užmaršumas. Juk kas žinotu apie Aleksandrą arba Cezarị, kas stebètųi stoikais arba peripatetikais, jeigu rašytojai nebūtų prisiminimų apie juos užrašę? Kas sektų apaštalų ir pranašų pèdsakais, jeigu būsimosioms kartoms jie nebūtu šventaisiais rašmenimis paženklinti?

Triumfo arkos tik tada garsina didžių vyru šlovę, kai ant jų iškaltas užrašas pasako, kodèl ir kam jos buvo pastatytos. Šitaip žiūrovas tik iš užrašo kaip trium- 
fatorių atpažǐsta mūsų Britanijos pagimdytą tèvynès išvaduotoją taikos skleidèją Konstantiną. Juk niekas niekada negarsètų tvaria šlove, jeigu jis pats arba kas nors kitas jos nebūtų aprašęs. Nedaug laiko turètų praeiti, kad kvailio šlovè prilygtų imperatoriaus šlovei, nebent abiejų atminimą metraštininkų labdara pratęstų. Kiek daug ir kokių didžių buvo karalių, apie kuriuos dabar niekas nekalba ir nemąsto? Todèl tiems, kurie siekia šlovès, nėra geresnio patarimo kaip pelnyti išsilavinusiu vyrų ir rašytoju palankumą. Juk niekam nenaudingi būtų nuolatinès tamsos apsupti ju šaunūs darbai, jeigu nebūtų raidžių šviesa nušviesti. Kiekvienas kaip nors kitaip pelnytas pritarimas arba pašlovinimas niekuo nesiskiria nuo tų plojimų, kuriuos vaidinimo metu gauna Echonè: jie baigiasi ten pat, kur prasideda.

Be to, iš raštų tikrai galima pasisemti sielvarte paguodos, darbuose poilsio, skurde pasitenkinimo, turtuose ir malonumuose saiko, nes saldžiu ir nuostabiu malonumu siela vaduojama iš ydų nelaisvès ir dargi nelaimèje maloniai gaivinama, kai savo įžvalgumą nukreipia į naudingą skaitymo ir rašymo veiklą. Tarp visų žmogiškų užsiėmimų nerasi nẻ vieno mielesnio ar naudingesnio, išskyrus galbūt tă Dievo valia skirtą pamalduma, prašant pokalbio su Dievu arba meilès išplèsta širdimi i sielą priimant Dievą ir Jo didžius darbus savyje lyg kad mąstymo galia svarstant. Patikèk patyrusiu, kad visas pasaulio saldumas, su šiuo užsièmimu palygintas, yra kartus. Ir taip yra dar labiau tam, kuris yra jautresnis ir remiasi grynais nesugadinto pagavaus proto sprendimais.

Todèl nedera stebètis, kodèl nepasinaudojau tavo patarimu kilti kai kuriomis laiptų pakopomis, kuriomis dabar kylama. Kodèl man nerūpi didieji dvaro reikalai, tau atsakysiu žodžiais Isokrato, kuris, draugų paklaustas, kodèl neužsiima forumo reikalais, atsakè: Ka toji vieta žino, aš nežinau. Ka aš žinau, toji vieta nežino (Macrobii 1560: liber VII, 1), nes aš niekinu tai, kas dvaro veikėjams rūpi, o tai, kas man rūpi, jie niekina. Labiau dera stebètis, kodèl neperkirtau arba nenutraukiau virvès - jeigu kitaip išsipainioti nebuvo galima, - kuri praeityje mane taip ilgai laikè ir vis dar tebelaiko tokioje vergiškoje dvaro pramogų nelaisvëje.

Mane, ilgai besiruošusị kitokiam gyvenimui, liūdina tai, kad jau beveik dvylika metų tuščiai praleidau: juk maitintam vaisingu šventosios filosofijos pienu, o vèliau nuo krūties nujunkytam, labiau tiktų leisti laiką filosofuojančiųjų draugijoje negu pramogaujančiujuc kompanijoje. Jaučiu, kad ir tu esi panašioje padètyje, nebent teisingesnejje ir garbingesneje, nes darai tai, kas tinkama, visada nepajudinamai stovėdamas ant tvirto dorybės pamato, nesijaudindamas dèl tuščių dalykų ir nesivaikydamas malonumų, bet icsakinèdamas pačiai tuštybei, kuri valdo pasauli. Todèl tuo metu, kai ivairios provincijos tave visaip šlovina tarsi statydamos tau triumfo arką, aš, vyras plebëjas, savo tiesmuka šios knygos iškalba tarsi džeržgiančiais švilpynės garsais tave šlovinu lyg pridėdamas akmenèli prie tavo šlovės kalno ir žinodamas, kad nors ji neturi malonumą teikiančio grakštumo, tačiau iš atsidavimo parašyta negali nepatikti.

Joje rašoma apie dvariškių pramogas, ypač apie tas, kurios yra žalingesnės. Joje rašoma ir apie filosofų paliktus pėdsakus; kuriais iš jų verta žengti, o kurių reikia 
vengti - paliekama išmintingo žmogaus sprendimui. O kad niekam nebūtu pakenkta, tą knygą reikia skirti tam, kuriam negalima įtarti esant būdinga jokios tuštybẻs, tau, pavyzdingiausiam mūsų laikų vyrui, ją dera dedikuoti; ir kad būtų parodyta tai, kas tokių kaip aš yra peiktina. Juk savo kvailystes atpažinęs skaitytojas ar klausytojas joje esanti pamokymą priims i savo sielą: juk, pakeitus varda, pasakojimas apie ji kalba; ypač kad visi žinos, kokia daugybe rimtų darbų tu nuolatos esi užsiẻmęs. Juk Seneka, patarinėdamas savo Liucilijui, moko ir kitus žmones. Jeronimas rašo Okeanui ir Pamachijui, bet kartu ir daugelio kitu asmenų nesaikingumą pažaboja.

Tačiau jei kas nors norètu pateisinti meilikautojo daromas kvailystes, turètu ivertinti kvailiojimo laika, ir (jeigu jis yra išmintingas) apie tai, kas pasakyta, turètu spręsti atsižvelgdamas i pasakymo priežastis. Bet jei kam nors pasirodytų, kad žodžiai skamba per šiurkščiai, jis turètu žinoti, kad jie tikrai pasakyti ne apie ji, bet apie mane ir i mane panašius, tuos, kurie geidžia kartu su manimi pasitaisyti, arba apie mirusius, kurie visiems priekaištams yra abejingi. Juk žinoma, kad Achilo nesėkmè dabar jau nieko nebejaudina, todèl dabartinè žmonių karta bus pataisyta, praeiti vertinant taip, kaip ji to nusipelno. Taip Horacijus, noredamas pasitaisyti, gruodžio mėnesiais savo vergams leisdavo naudotis laisve:

Kiekvieną jo ydą klastingasis Flakas primena besijuokiančiam draugui

ir jo paties leidimu jo sieloje žaidžia (Persi 1843: Satura I, 115-116).

O tai, kas įvairių autorių veikaluose liečia mūsų reikalo esmę, iš atminties paminejjau, kartais nenurodydamas ju autorių vardų ne tik dèl to, kad tau, taip plačiai apsiskaičiusiam, jie yra žinomi, bet ir dèl to, kad mažiau išprususius paskatinčiau idèmiau skaityti. Jeigu tuose dalykuose kas nors tolèliau nuo tikrojo tikèjimo nutolsta, esu tikras, kad man už tai bus atleista, nes aš nežadu, jog viskas, kas čia parašyta, yra tikra, bet tai, kas tikra, ir tai, kas melaginga, itraukta, kad tarnautu skaitytoju naudai. Ir aš nesu toks neišmanèlis, kad už tiesą laikyčiau pasakojima, kaip sparnuotas paukštis su vėžliu kalbejosi arba kaip kaimo pelè miesto pelę prièmé pasisvečiuoti savo varganame būste ir t. t., bet neabejoju, kad tokie pramanai tarnauja pamokymui. Tie dalykai, kuriais dažniausiai naudojuosi, yra svetimi, o tai, kas visur gerai pasakyta, priklauso man, ir tas savo mintis išreiškiu kartais santrumpomis, o kartais patikimai ir užtikrintai išsakau svetimais žodžiais.

Ir kadangi jau pradejjau atskleidinèti savo sumanymo paslaptis, tai dabar dar labiau apnuoginsiu savo izžūlumą. Visus, kurie žodžiais ir darbais man atrodo esą filosofai, pasitelkiau kaip savo valdinius, ir dar daugiau, netgi kaip vergus, kurie savo pamokymais mane nuo šmeižiku gina, nes ir aš juos giriu kaip autorius. Juk aš nemačiau nei Aleksandro, nei Cezario, negirdejau Sokrato arba Zenono, Platono arba Aristotelio pokalbių, tačiau iš jų ir kitu, vienodai man nepažistamų autorių, paėmiau daugybę skaitytojams naudingų dalykų. Kad neatrodyčiau mėgstančiu ginčytis, kad nebūčiau apkaltintas piktnaudžiaujantis melu ir kad nuraminčiau pavyduolius, nes ir aš turiu savo Kornifikiją (Virgilijaus šmeižikas) ir Lanviną (ži- 
nomas pavyduolis, Terencijo amžininkas), atvirai prisipažistu esąs kaltas melavimu, nes Biblijoje parašyta, kad visi žmonés - melagiai (Ps 116, 11). Todèl tenesitiki mūsų Lanvinas, kad jo plati krūtinè, išpampęs pilvas, ištinęs ir išraudęs veidas bei akiplěšiškas, tuščiakalbis liežuvis, visada labiau pasiruošęs žlugdyti svetimus, negu taisyti savus, ji išgelbès. Kas jis yra, aš pasakysiu, jeigu jis nesiliaus užgauliojęs. Tada jis aiškiai supras, kad solidus amžius nesuteikia ir neišsaugo geros reputacijos. Bet jeigu jis parodys ir įrodys mano argumentų arba patarimų melaginguma, aš, net priešo žodžių skatinamas, nevengsiu pasitaisyti. Priešingai, draugu vadinsiu kiekviena, kuris ištaisys mano klaidą.

Jeigu pasirodytų, jog kuris nors autorius rašo kitaip, negu aš, tai dèl to nedera manęs kaltinti meluojant, nes karo reikaluose aš remiuosi istorikais, kurie dažnai vienas kitam prieštarauja, o filosofijos dalykuose vadovaujuosi akademikais, kurie nurodo, kad pasirinktina tai, kas atrodo tikètiniausia. Ir man ne gèda prisipažinti, kad tuose reikaluose, kurie išmintingam žmogui atrodo abejotini, ištikimai seku akademikų pėdomis. Ir nors atrodo, kad ši filosofijos mokykla visus dalykus padarè abejotinus, tačiau jokia kita mokykla nèra taip smarkiai atsidavusi tiesos tyrimui. Be to, Ciceronas, kuris senatvejje tapo jos šalininku, savo autoritetu liudija, kad jokia kita filosofijos mokykla nèra palankesnè pažangai. Todèl tų pasisakymų apie apvaizdą likima, laisvą apsisprendimą ir panašius dalykus atžvilgiu man yra artimesnis akademikų požiūris negu lengvabūdiški teiginiai tų, kurie apie abejotinus dalykus neapgalvotai kalba. Be to, kartais aš naudojuosi Rašto liudijimais kaip puikia minčių aiškinimo priemone. Tačiau tai darau ne taip, kad kas nors priešinga tikèjimui ir geriems papročiams iš to kiltu, o taip, kad tiek naujas, tiek senas mintis nekintanti tiesa gimdytų. Ne visos iš veido vienodos, Betgi ir skirias nedaug, kaip sesèms tikrosioms pritinka (Ovidijus 1979: 35).

Viskas palikta tavo tyrimui, kad didesnè ir teisingesnè garbė atitektų tau už klaidų ištaisymą, negu man už parašymą. Tai, kad skirtingos knygos dalys nevienodai gerai parašytos, lèmė įvairūs mano užsièmimai dvare, dèl kurių kartais sunkiai rasdavau laiko rašyti. Tačiau tuo metu, kai tu buvai užsièmęs Tulūzos apsiaustimi ${ }^{1}$, aš, trumpam nusišalinęs nuo dvariškių tuščių užsièmimų, pradẻjau rašyti, manydamas, kad laisvalaikis neužsiimant mokslais yra mirtis ir gyvo žmogaus palaidojimas (Seneka 1986: 237)². Jei kas nors drauge su Lanvinu šmeižtų nežinomą arba pramanytą autorių, tai tegul kaltina Platona, Cicerono Afrikiečio sapna ir tuos filosofus, kurie saturnalijose dalyvauja, arba palankiai žiūri i̇ mūsų rašytoju pramanus, jeigu jie valstybės labui tarnauja. Be to, visomis savo galiomis skaitytojo ir klausytojo nuolankiai prašau savo maldose Tẻvą prašyti pasigailëjimo man ir melsti, kad gaučiau atleidimą už klaidas, kurių, uoliai dirbdamas, padariau didžiulę daugybę. Juk ir aš, tikiuosi, priklausau visiems tiems, kurie bijo Dievo. Juk ir aš pakaitomis širdimi ir balsu meldžiuosi už stokojančiuosius, kad mūsu darbus ir mintis visagalis ir gailestingas Dievas nuo paklydimų apsaugotų ir kad didžiojo teismo angelai savo dvasia teiktųsi apšviesti mūsų protus, kad ydingų žmonių klaidos mūsų neužvaldytų. 


\section{Literatūra}

Macrobii Ambrosii Aurelii Theodosii. 1560. Saturnaliorum Libri Septem. Lyon: Paganum. <https:// penelope.uchicago.edu/Thayer/L/Roman/Texts/ Macrobius/Saturnalia/7*.html> [žr. 202102 26]

Ovidijus. 1979. Metamorfozés. Iš lotynų k. vertė Antanas Dambrauskas. Vilnius: Mintis.

\section{Nuorodos}

11159 m. Tomas Beketas (Thomas Becket), Britanijos karalystès kancleris, organizavo Tulūzos apsiaustị, kuriai vadovavo karalius Henrikas II.
Persi Auli Flacci. 1843. Saturae. Ed. Otto Jahn. Leipzig: Breitkopf. <https://www.thelatinlibrary.com/ persius.html\#V> [žr. 202102 26]

Seneka. 1986. Laiškai Liucilijui. Iš lotynų k. vertè Dalia Dilytè. Vilnius: Mintis.

2 Laisvalaikis neužsiimant mokslais yra mirtis ir gyvo žmogaus palaidojimas.

Iš lotynų kalbos vertė prof. dr. Gintautas VYŠNIAUSKAS

Klaipėdos universitetas

Versta iš Ioannis Saresberiensis episcopi Carnotensis Policratici sive De nugis curialium et vestigiis philosophorum libri 8; recognovit et prolegomenis, apparatu critico, commentario, indicibus instruxit Clemens C.I. Webb. 1909. Oxonii E Typographeo Clarendoniano <https://archive.org/details/ioannissaresberi01johnuoft/page/n13/mode/2up> [žr. 202102 26] 